\title{
Effects of marble, timber, and glass powder as partial replacements for cement
}

\author{
Bassam A. Tayeh \\ Civil Engineering Department, Faculty of Engineering, Islamic University of Gaza, Gaza, \\ Palestine \\ E-mail: btayeh@iugaza.edu.ps
}

\begin{abstract}
Waste materials, such as glass, marble, and timber, are pressing environmental problems worldwide, and their environmental impact can be best overcome by reusing them. This research mainly aims to determine the impact of using waste materials, such as crushed glass, crushed marble, and burned wood in powder form, as partial replacements for cement on the compressive strength of concrete. Mechanical properties (e.g., compressive strength) and physical properties (e.g., workability and unit weight) were investigated. The powdered waste materials (after passing through sieve \#200) were partially replaced with cement by ratios of $10 \%, 20 \%$, and $30 \%$. Compressive strength was tested on the 7 th, 28 th, and 56th days. Results showed that workability decreased as the partial replacement level of glass powder, marble powder, and timber ash increased. The results also showed a decrease in the compressive strength of concrete when the replacement level was increased from $10 \%$ to $30 \%$ for each waste material.
\end{abstract}

Keywords: Compressive strength; Concrete; Glass powder; Marble powder; Cement replacement; Timber ash; Waste material

\section{Introduction}

Waste utilization is an attractive alternative to disposal given that disposal cost and potential pollution problems are reduced or even eliminated while simultaneously conserving resources. The reuse of waste is important from multiple points of view; it helps save and sustain nonrenewable natural resources, decreases pollution, and helps save and recycle energy in production processes. [1] The reuse of industrial solid waste as partial replacement for aggregates in construction activities not only saves landfill space but also reduces the demand for extracting natural raw materials.

Reference [2] determined that the use of marble dust as cement replacement or sand replacement in concrete production gradually enhances the mechanical and physical properties of concrete, particularly with low waterto-cement (w/c) ratio. Reference [3] found that the flexural strength of waste marble mix concrete increases with an increase in the waste marble ratio in these mixtures. The mean strength of all concrete mixes with marble granules was 5\%-10\% higher than the reference concrete that conformed to IS: 456-2000.

The main purposes for using fly ash in high-strength concrete are to reduce heat generation and improve durability properties [4]. Fly ash generally improves workability and contributes to strength development, and hence, it is considered an effective cementitious component of concrete. Fly ash is used in concrete to achieve energy conservation, along with economic, ecological, and technical benefits [5] [6]. It is used as a pozzolanic mineral admixture in concrete. ASTM C125 indicates that pozzolan is either a siliceous or a siliceous and aluminous material with minimal or no cementitious value but can be finely divided from and in the presence of moisture. Pozzolan chemically reacts with calcium hydroxide at ordinary temperatures to form compounds with cementitious properties.

Reference [7] showed that the use of glass powder as a partial replacement for fine aggregates in concrete helps reduce expansion by $66 \%$ and increases the flexural strength and compressive strength of specimens with a specific percentage of glass powder.

The use of glass powder reduces the chloride ion penetrability of concrete, which decreases the risk of chloride-induced corrosion in the steel reinforcement of concrete, and thus, enhance durability results and contribute to construction sustainability [8] [9].

The present study aims to investigate the possibilities of reusing waste marble powder, timber ash, and glass powder as partial replacements for cement to modify concrete mix properties. This objective is achieved by studying the effects of replacing cement with marble powder, timber ash, and glass powder that were passed through sieve \#200 on the physical properties of the concrete mix.

\section{Experimental Program}


The experimental program was divided into two parts. First, the laboratory investigation consisted of tests for fresh and hardened concrete. Fresh concrete was tested for slump to ensure the workability of the mix, whereas hardened concrete was tested for compression and unit weight. Second, constituent material properties were tested for sieve analysis, fineness, unit weight, specific gravity, moisture content, absorption, and degradation resistance.

\subsection{Description of the samples}

Cube samples were prepared using four different concrete mixes. Each mix varies from the others in terms of replacement type. Each replacement was prepared in three proportions. Table 1 provides the replacement percentage. Different tests for unit weight, slump, compressive strength, and cube density were conducted for each mix on the 7th, 28th, and 56th days.

Table 1. Percentage of ceent replacement

\begin{tabular}{cc}
\hline Replacement Type & percentage \\
\hline Timber Ash & $10 \%, 20 \%, 30 \%$ \\
Marble Powder & $10 \%, 20 \%, 30 \%$ \\
Glass Powder & $10 \%, 20 \%, 30 \%$ \\
\hline
\end{tabular}

\subsection{Materials}

The materials used in this study were Portland cement (Type I), natural aggregates, sand, water, timber ash, glass powder, and marble powder.

\subsubsection{Cement}

Portland cement (Type I) was used throughout the investigation. The cement properties are as follows.

The fineness degree of cement is a measure of the mean size of grains in the cement. The hydration and hydrolysis rates, and the consequent development of strength, depend on the fineness of cement. Fineness has been standardized to establish the same rate of hardening in different cement brands. Fine cement exhibits fast action with water and gains early strength although its ultimate strength remains unaffected. However, the shrinkage and cracking of cement will increase with its fineness [10].

$$
S=S S * \frac{\sqrt{T}}{\sqrt{T s}}
$$

Where,

S: specific surface of test sample $\left(\mathrm{cm}^{2} / \mathrm{g}\right)$

Ss: specific surface of standard cement $\left(\mathrm{cm}^{2} / \mathrm{g}\right)$

$\mathrm{T}$ : time interval of manometer drop for test sample (sec)

Ts: time interval of manometer drop for standard cement (sec)

$$
S=486 * \sqrt{54}=3571.4 \mathrm{~cm}^{2} / \mathrm{g}
$$

\subsubsection{Water}

Potable tap water without salts or chemicals was used in the study. The water source was the soil and material laboratory in the Islamic University of Gaza.

\subsubsection{Natural aggregates}

Two main categories of aggregates, namely, coarse and fine aggregates, were used. The classification of aggregates into fine and course was in accordance with [11].

1) Natural coarse aggregates

The coarse aggregates used in this study were crushed limestone. Three sizes of coarse aggregates were used, with the maximum nominal size of $25 \mathrm{~mm}$ and the minimum size of $4.75 \mathrm{~mm}$. These aggregates are commonly used by Gaza concrete manufacturers and are locally known as Foliya, Adasiya, and Simsymia. Table 2 shows the size of the three aggregate types.

Table 2. Used aggregates types

\begin{tabular}{cc}
\hline Commercial Name Used in Gaza & Size Fraction (mm) \\
\hline Foliya & $25-19$ \\
Adasiya & $19-9.5$ \\
Simsymia & $9.5-4.75$ \\
\hline
\end{tabular}

Aggregate specific gravity is a dimensionless value used to determine the volume of aggregates in concrete mixes. Table 3 presents the specific gravity results of all natural coarse aggregates used in preparing the concrete mixes. The specific gravity of coarse and fine aggregates was determined according to References [12] and [13], respectively. Specific gravity was calculated under dry and saturated surface conditions. 
Table 3. Aggregate specific gravity

\begin{tabular}{ccccccc}
\hline Aggregate type & SSD wt.(g) & Dry wt.(g) & Wt. in water(g) & Gsb $($ dry $)$ & Gsb (SSD) & Abs.\% \\
\hline Type 1 $(25 \mathrm{~mm})$ & 2008 & 1973 & 1194 & 2.424 & 2.467 & 1.789 \\
Type 2 $(19 \mathrm{~mm})$ & 2015 & 1964 & 1208 & 2.411 & 2.496 & 2.6 \\
Type 3 $(9.5 \mathrm{~mm})$ & 1901 & 1872 & 1155 & 2.509 & 2.548 & 1.6 \\
\hline
\end{tabular}

Aggregate moisture content is the percentage of water present in a sample of aggregates, either inside the pores or on the surface. The moisture content of coarse and fine aggregates was determined according to [14]. Moisture content was $0.23 \%$ for all aggregate types. The equipment used in this test included a dry oven and a weighing balance.

The unit weight or bulk density of aggregates is the weight of aggregates per unit volume. The bulk density value is required to select concrete mixture proportions. The procedure presented in [15] was used to determine aggregate bulk density. Table 4 provides the aggregate unit weight values. The equipment used in this test included a weighing balance and a cylindrical metal container.

Table 4. Aggregate absorption, Unit Weight

\begin{tabular}{ccc}
\hline Aggregate Type & Unit Weight $\left(\mathbf{g} / \mathbf{c m}^{\mathbf{3})}\right.$ & Absorption \% \\
\hline Type 1 $(25 \mathrm{~mm})$ & 1.476 & 1.789 \\
Type 2 $(19 \mathrm{~mm})$ & 1.448 & 2.6 \\
Type 3 $(9.5 \mathrm{~mm})$ & 1.507 & 1.6 \\
\hline
\end{tabular}

The absorption of aggregates is the weight of water present in aggregate pores, which is expressed as the percentage of aggregate dry weight. Reference [12] was used to determine coarse aggregate absorption, whereas Reference [13] was used to determine fine aggregate absorption. Table 4 provides the absorption percentages of all aggregates.

The sieve analysis of aggregates includes the determination of coarse and fine aggregates by using a series of sieves. The procedure in Reference [16] was used to determine the sieve analysis of course and fine aggregates. The sieve grading used for the three types of coarse aggregates fits the requirements in Reference [11].

The Los Angeles abrasion test is a measure of the degradation of mineral aggregates with standard grading, which results from a combination of actions that include abrasion or attrition, impact, and grinding in a rotating steel drum that contains a specified number of steel spheres. The Los Angeles abrasion test is widely used as an indicator of the relative quality or competence of mineral aggregates.

$$
\text { abration }=\frac{a-b}{a} * 100
$$

where,

a: dry weight of sample

b: amount retained on $1.7 \mathrm{~mm}$ sieve

$$
\text { abration }=\frac{5000-4336}{5000} * 100=13.28 \%
$$

2) Natural fine aggregates

The sieve grading used for the fine aggregates fits the requirements of Reference [11]. The natural fine aggregates were tested for physical properties, as shown in Table 5.

Table 5. Physical Properties of Crushed Stone

\begin{tabular}{ccc}
\hline Gsb Dry & Absorption \% & Dry unit weight $(\mathrm{kg} / \mathrm{m} 3)$ \\
\hline 2.65 & 2.26 & 1610.01 \\
\hline
\end{tabular}

\subsubsection{Timber ash}

Timber ash was obtained from the remains of burning timber. It was passed through sieve \#200 to achieve the same level of cement fineness. Timber ash is shown in Figure 1.

Fineness of Timber ash has measured by air permeability test

Where:

$$
S=S s * \frac{\sqrt{T}}{\sqrt{T s}}
$$

S: Specific surface of test sample $(\mathrm{cm} 2 / \mathrm{g})$

Ss: Specific surface of standard cement $(\mathrm{cm} 2 / \mathrm{g})$ 
T: Time interval of manometer drop for test sample (sec)

Ts: Time interval of manometer drop for standard cement (sec)

$$
S=486 * \sqrt{200}=6873 \mathrm{~cm}^{2} / g
$$
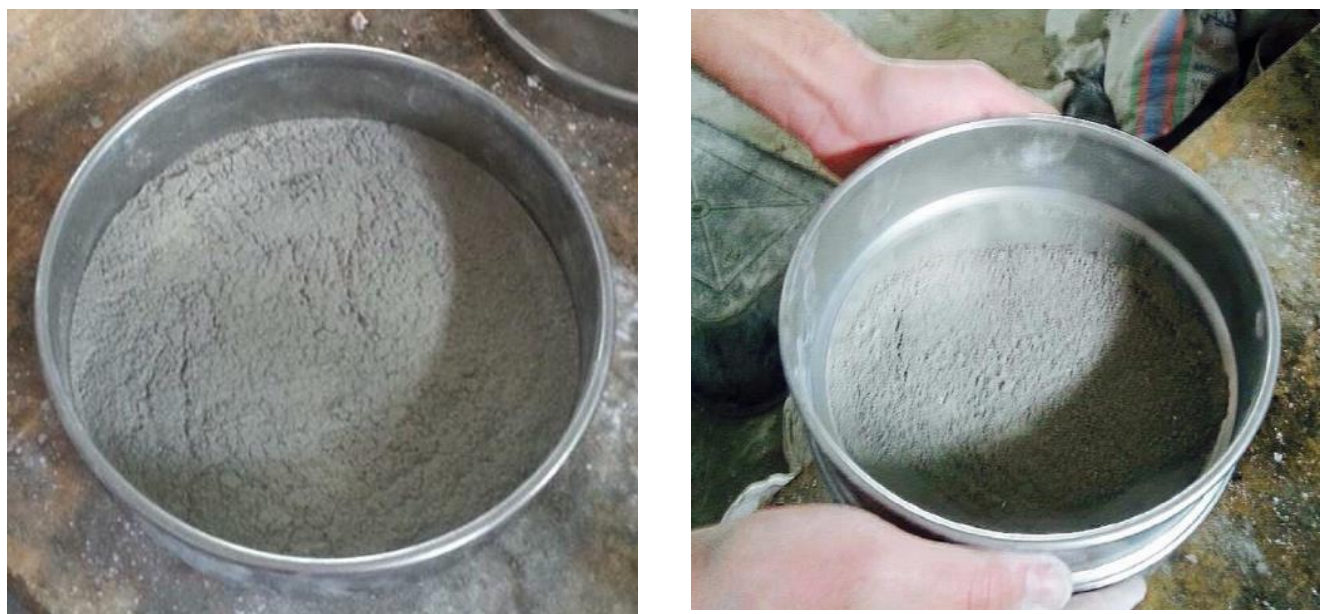

\subsubsection{Glass powder}

Figure 1. timber ash preparing

Glass powder was prepared to achieve the same fineness as cement. Glass preparation has two stages.

First, the glass sample was ground using a Los Angeles machine with 6000 revolutions, as shown in Figure 2.

Stage II: Sieve the sample on a sieve\#200 as shown in the Figure 3.

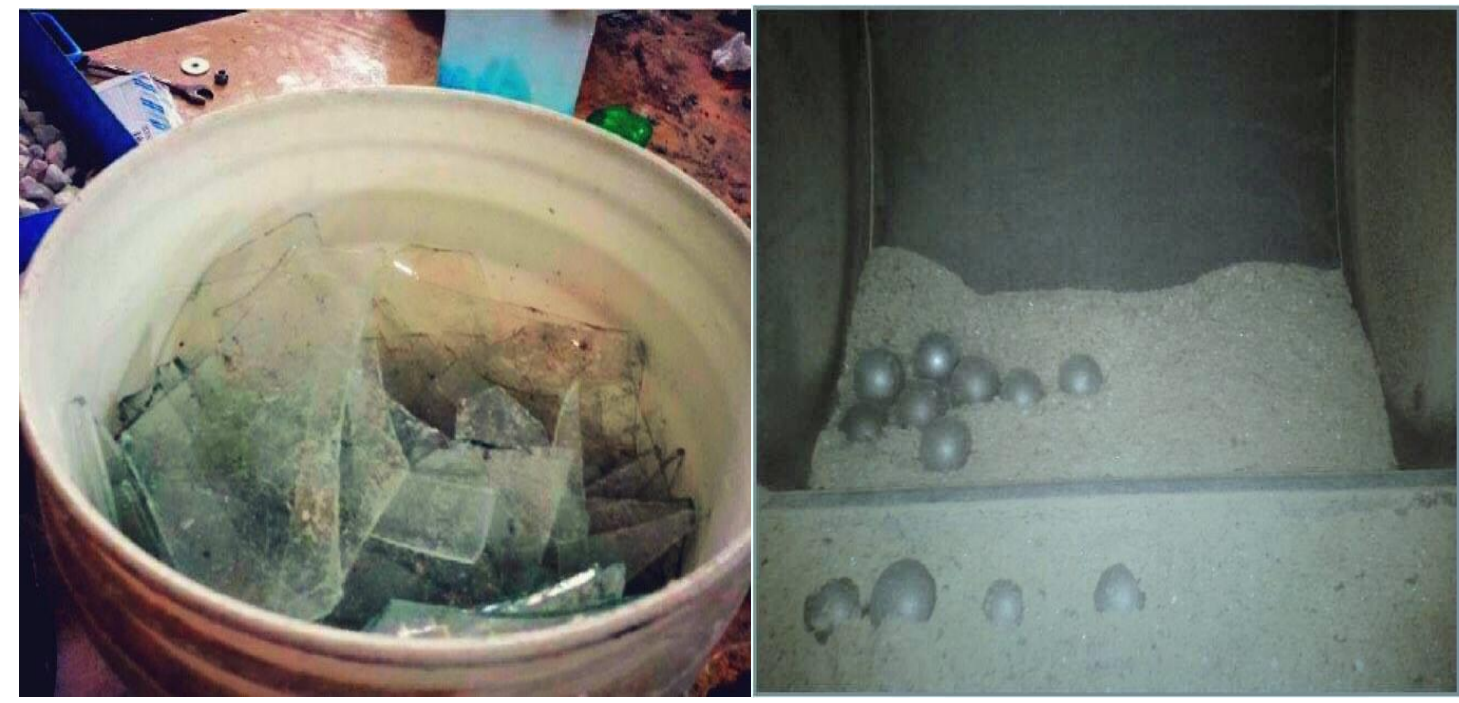

Figure 2. Stage I of glass preparing

Fineness of glass powder has measured by air permeability test

$$
S=S s * \frac{\sqrt{T}}{\sqrt{T s}}
$$

Where:

S: Specific surface of test sample $(\mathrm{cm} 2 / \mathrm{g})$

Ss: Specific surface of standard cement $(\mathrm{cm} 2 / \mathrm{g})$

$\mathrm{T}$ : Time interval of manometer drop for test sample (sec)

Ts: Time interval of manometer drop for standard cement $(\mathrm{sec})$

$$
S=486 * \sqrt{45}=3260.18 \mathrm{~cm}^{2} / \mathrm{g}
$$




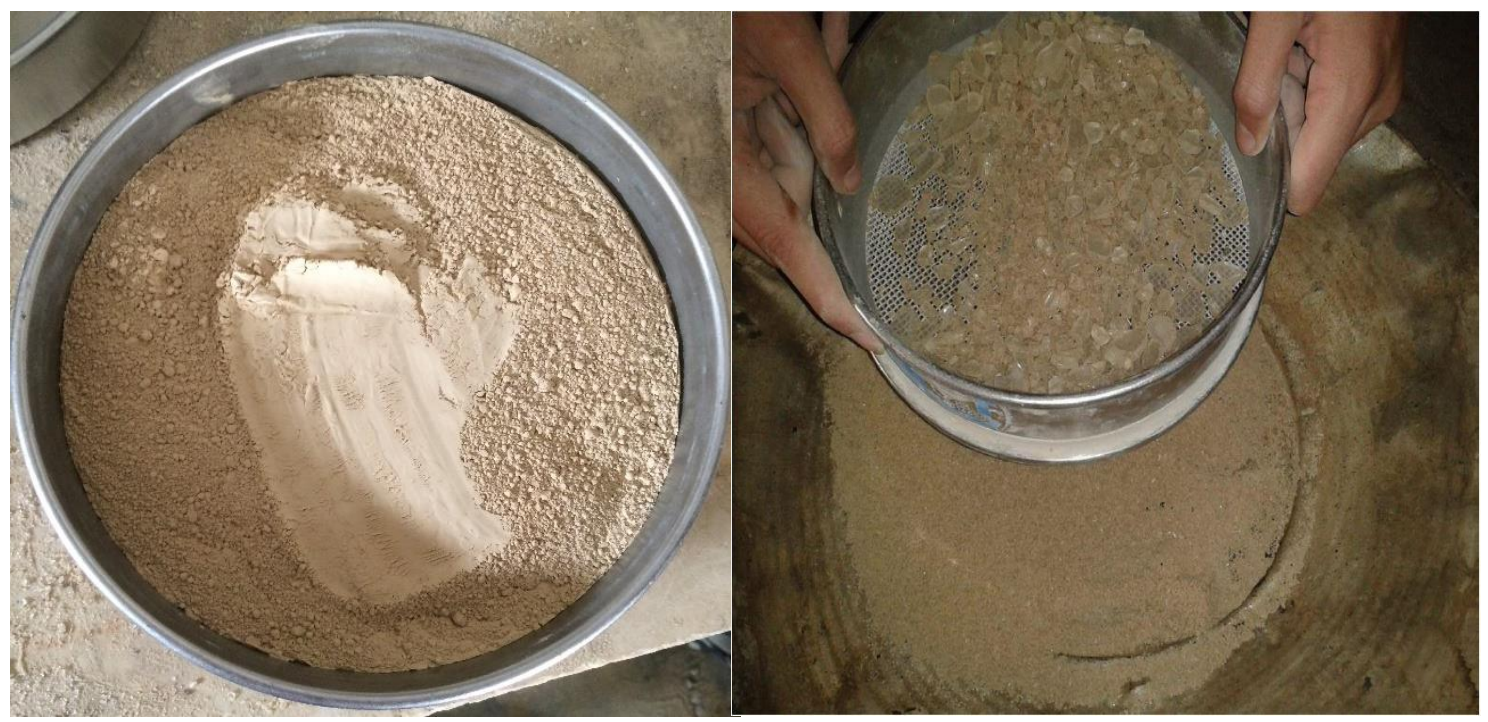

Figure 3. Stage II of glass preparing

\subsubsection{Marble powder}

Marble powder was collected from marble factories and passed through sieve \#200 to achieve the same level of cement fineness. Marble powder is shown in Figure 4.
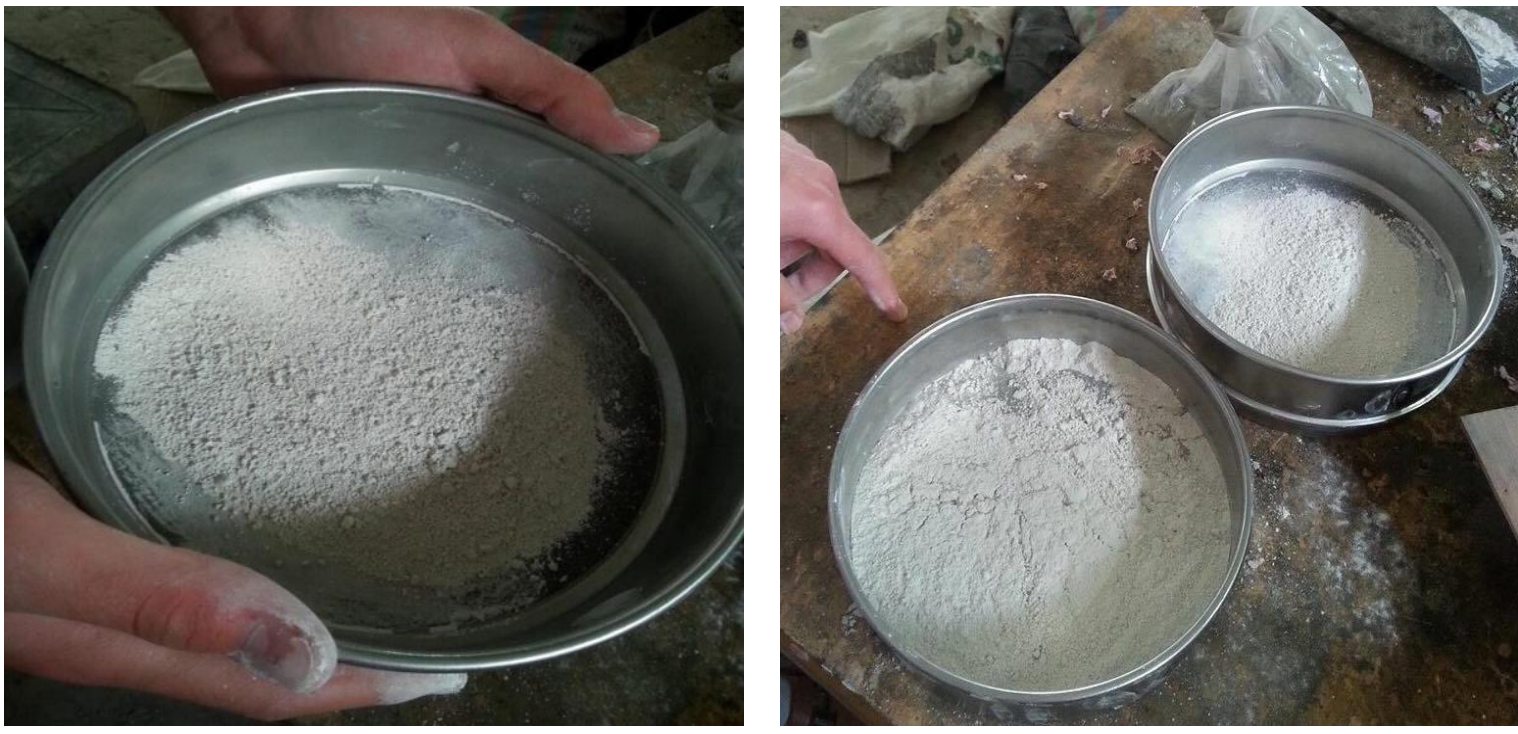

Figure 4. Marble powder preparing

Fineness of marble powder has measured by air permeability test

$$
S=S s * \frac{\sqrt{T}}{\sqrt{T s}}
$$

Where:

S: Specific surface of test sample $(\mathrm{cm} 2 / \mathrm{g})$

Ss: Specific surface of standard cement $(\mathrm{cm} 2 / \mathrm{g})$

$\mathrm{T}$ : Time interval of manometer drop for test sample (sec)

Ts: Time interval of manometer drop for standard cement (sec)

$$
S=486 * \sqrt{187}=6645.9 \mathrm{~cm}^{2} / \mathrm{g}
$$

\subsection{Job mix}

The aggregates used to prepare the mixtures were as follows: (a) aggregates with a maximum size of 25-19 $\mathrm{mm}$ (Foliya), (b) aggregates with a maximum size of 19-9.5 mm (Adasiya), and (c) aggregates with a maximum 
size of 9.5-4.75 mm (Simsimiya). Table 6 shows the weight of each component of concrete mix for B300 concrete in $\mathrm{kg} / \mathrm{m} 3$.

Table 6. Concrete mix proportions

\begin{tabular}{|c|c|c|c|c|}
\hline \multirow[b]{2}{*}{ Mix Content } & \multicolumn{4}{|c|}{ Replacement Percentage \% } \\
\hline & $\begin{array}{c}0 \% \\
\text { Wt. }\left(\mathrm{kg} / \mathrm{m}^{3}\right)\end{array}$ & $\begin{array}{c}10 \% \\
\text { Wt. }\left(\mathrm{kg} / \mathrm{m}^{3}\right)\end{array}$ & $\begin{array}{c}20 \% \\
\text { Wt. }\left(\mathrm{kg} / \mathrm{m}^{3}\right)\end{array}$ & $\begin{array}{c}30 \% \\
\text { Wt. }\left(\mathrm{kg} / \mathrm{m}^{3}\right)\end{array}$ \\
\hline Coarse Aggregate Type 1 (25mm) & 660 & 660 & 660 & 660 \\
\hline Coarse Aggregate Type $2(19 \mathrm{~mm})$ & 430 & 430 & 430 & 430 \\
\hline Coarse Aggregate Type $3(9.5 \mathrm{~mm})$ & 210 & 210 & 210 & 210 \\
\hline Sand & 660 & 660 & 660 & 660 \\
\hline Water & 200 & 200 & 200 & 200 \\
\hline Cement & 330 & 297 & 264 & 231 \\
\hline Marble powder & 0 & 33 & 66 & 99 \\
\hline Timber Ash & 0 & 33 & 66 & 99 \\
\hline Glass powder & 0 & 33 & 66 & 99 \\
\hline Admixture & 2.4 & 2.4 & 2.4 & 2.4 \\
\hline
\end{tabular}

\section{Results and Discussion}

\subsection{Glass powder passing through sieve \#200}

\subsubsection{Density}

Table 7 shows the average density of the concrete specimens at the $7 \mathrm{th}, 28 \mathrm{th}$, and 56th days. As the partial replacement level of glass powder with cement in concrete increases, the density of the concrete specimens decreases.

Table 7. Average density of concrete specimens at 7,28 and 56 days, containing glass powder

\begin{tabular}{cccc}
\hline $\begin{array}{c}\text { Percentage } \\
\text { replacement }(\%)\end{array}$ & $\begin{array}{c}\text { Density }\left(\mathrm{Kg} / \mathrm{m}^{3}\right) \\
\text { at 7days }\end{array}$ & $\begin{array}{c}\text { Density }\left(\mathrm{Kg} / \mathrm{m}^{3}\right) \\
\text { at 28days }\end{array}$ & $\begin{array}{c}\text { Density }\left(\mathrm{Kg} / \mathrm{m}^{3}\right) \\
\text { at 56days }\end{array}$ \\
\hline 0 & 2400.42 & 2368 & 2323 \\
10 & 2323.8 & 2295.9 & 2295.9 \\
20 & 2334.5 & 2330.9 & 2283 \\
30 & 2293.2 & 2316.9 & 2271.5 \\
\hline
\end{tabular}

\subsubsection{Workability (slump test)}

The slump value was used to indicate the mix workability of fresh concrete. Table 8 presents the average slump test results of fresh concrete. At 0\% replacement of glass powder, the slump was $18 \mathrm{~mm}$. At $10 \%$ replacement of glass powder, the slump decreased to $17 \mathrm{~mm}$. At $20 \%$ replacement of glass powder, the slump decreased to $15.5 \mathrm{~mm}$. At $30 \%$ replacement of glass powder, the slump decreased to $14.5 \mathrm{~mm}$. These results show that workability decreases when the percentage of glass powder is increased. $[17,18]$

Table 8.Average slump test of fresh concrete, containing glass powder

\begin{tabular}{cc}
\hline percentage replacement $(\%)$ & Slump $(\mathrm{mm})$ \\
\hline 0 & 18 \\
10 & 17 \\
20 & 15.5 \\
30 & 14.5 \\
\hline
\end{tabular}

\subsubsection{Compressive strength test results}

Table 9 indicates the influence of glass powder replacement with cement on the compressive strength of the concrete cubes. The results demonstrated that the inclusion of glass powder reduced the strength at the 7th, 28th, and 56th days. For 0\% replacement, the compressive strength results were 22.4, 31.2, and $33.3 \mathrm{MPa}$ at the 7 th, 28 th, and 56th days, respectively. The compressive strength values at the 7 th day decreased to $2.2 \%, 8.9 \%$, and $25.8 \%$, and subsequently, to $3.2 \%, 7.6 \%$, and $30.1 \%$ at the 28 th day for $10 \%, 20 \%$, and $30 \%$ glass powder replacement, respectively. The compressive strength results at the 56th day also decreased to $0 \%, 8.4 \%$, and $19.8 \%$ for $10 \%, 20 \%$, and $30 \%$ glass powder replacement, respectively.

\subsection{Marble powder passing through sieve \#200}

\subsubsection{Density}

Table 10 shows the average density of the concrete specimens at the 7th, 28th, and 56th days. As the partial replacement level of marble powder with cement in concrete increased, the density of the concrete specimens decreased. 
Table 9. Effects of use glass powder on compressive strength of concrete at different ages.

\begin{tabular}{|c|c|c|c|c|c|c|c|c|c|}
\hline \multirow{2}{*}{ Test } & \multirow{2}{*}{$\begin{array}{l}\text { Age of sample } \\
\text { (days) }\end{array}$} & \multicolumn{8}{|c|}{ Percentage of replacement } \\
\hline & & \multicolumn{2}{|c|}{$\mathbf{0 \%}$} & \multicolumn{2}{|c|}{$10 \%$} & \multicolumn{2}{|c|}{$20 \%$} & \multicolumn{2}{|c|}{$\mathbf{3 0 \%}$} \\
\hline \multirow{12}{*}{$\begin{array}{l}\text { Compressive } \\
\text { Strength } \\
(\mathrm{MPa})\end{array}$} & \multirow{4}{*}{7} & 21.5 & \multirow{4}{*}{22.4} & 21.8 & \multirow{4}{*}{21.9} & 20.7 & \multirow{4}{*}{20.4} & 16.5 & \multirow{4}{*}{16.62} \\
\hline & & 22.7 & & 21.5 & & 19.9 & & 16.2 & \\
\hline & & 23.7 & & 22.0 & & 20.1 & & 16.9 & \\
\hline & & 21.9 & & 22.3 & & 20.9 & & 16.7 & \\
\hline & \multirow{4}{*}{28} & 31.6 & \multirow{4}{*}{31.2} & 29.8 & \multirow{4}{*}{30.2} & 29.0 & \multirow{4}{*}{28.8} & 21.6 & \multirow{4}{*}{21.8} \\
\hline & & 31.3 & & 30.8 & & 28.4 & & 22.3 & \\
\hline & & 30.8 & & $* 17.1$ & & 28.7 & & 21.4 & \\
\hline & & 31.1 & & 30.2 & & 29.3 & & 21.9 & \\
\hline & \multirow{4}{*}{56} & 33.6 & \multirow{4}{*}{33.3} & $* 29.8$ & \multirow{4}{*}{35.3} & 30.1 & \multirow{4}{*}{30.5} & 27.3 & \multirow{4}{*}{26.7} \\
\hline & & 33.9 & & 35.5 & & 29.6 & & 25.3 & \\
\hline & & 32.8 & & 35.7 & & 32.1 & & 25.8 & \\
\hline & & 32.9 & & 34.8 & & 30.5 & & 28.7 & \\
\hline
\end{tabular}

*This value was excluded from average calculation

Table 10. Average density of concrete specimens at 7, 28 and 56 days, containing marble powder

\begin{tabular}{cccc}
\hline $\begin{array}{c}\text { Percentage } \\
\text { replacement }(\%)\end{array}$ & $\begin{array}{c}\text { Density }(\mathrm{Kg} / \mathrm{m} 3) \\
\text { at 7-days }\end{array}$ & $\begin{array}{c}\text { Density }\left(\mathrm{Kg} / \mathrm{m}^{3}\right) \\
\text { at 28 days }\end{array}$ & $\begin{array}{c}\text { Density }\left(\mathrm{Kg} / \mathrm{m}^{3}\right) \\
\text { at 56 days }\end{array}$ \\
\hline 0 & 2400.42 & 2368 & 2368 \\
10 & 2270.2 & 2306.8 & 2306.8 \\
20 & 2274.4 & 2277.9 & 2277.9 \\
30 & 2296.2 & 2299.5 & 2299.5 \\
\hline
\end{tabular}

\subsubsection{Workability (slump test)}

The slump value was used to indicate the mix workability of fresh concrete. Table 11 presents the average slump test results of fresh concrete. At $0 \%$ replacement of marble powder, the slump was $18.5 \mathrm{~mm}$. At $10 \%$ replacement of marble powder, the slump decreased to $17 \mathrm{~mm}$. At $20 \%$ replacement of marble powder, the slump decreased to $15.0 \mathrm{~mm}$. At $30 \%$ replacement of marble powder, the slump decreased to $13.5 \mathrm{~mm}$. These results show that when the percentage of marble powder is increased, workability decreases.

\begin{tabular}{cc} 
Table 11. Average slump test of fresh concrete, containing marble powder \\
\hline Percentage replacement $(\%)$ & Slump $(\mathrm{mm})$ \\
0 & 18.5 \\
10 & 17 \\
20 & 15 \\
30 & 13.5 \\
\hline
\end{tabular}

\subsubsection{Compressive strength test results}

Table 12 indicates the influence of marble powder replacement with cement on the compressive strength of the concrete cubes. The results demonstrated that the inclusion of marble powder reduced strength at the 7 th, 28th, and 56th days. For 0\% replacement, the compressive strength results were 22.4, 31.2, and 33.3 MPa at the 7th, 28th, and 56th days, respectively. The values at the 7th day compressive strength decreased to $8.9 \%, 23.2 \%$, and $33.4 \%$, and subsequently, to $2.5 \%, 20.5 \%$, and $39.1 \%$ at the 28 th day for $10 \%$, 20\%, and $30 \%$ marble powder replacement, respectively. At the 56th day, the compressive strength results also decreased to $0 \%$, $19.8 \%$, and $31.2 \%$ for $10 \%, 20 \%$, and $30 \%$ marble powder replacement, respectively.

\subsection{Timber ash passing through sieve \#200}

\subsubsection{Density}

Table 13 shows the average density of the concrete specimens at the 7 th, 28th, and 56th days. As the partial replacement level of timber ash with cement in concrete increased, the density of concrete specimens decreased.

\subsubsection{Workability (slump test)}

The slump value was used to indicate the mix workability of fresh concrete. Table 14 presents the average slump test results of fresh concrete. At $0 \%$ replacement of timber ash, the slump was $18.5 \mathrm{~mm}$. At $10 \%$ replacement of timber ash, the slump decreased to $17 \mathrm{~mm}$. At $20 \%$ replacement of timber ash, the slump 
decreased to $15.0 \mathrm{~mm}$. At $30 \%$ replacement of timber ash, the slump decreased to $13.5 \mathrm{~mm}$. Therefore, workability decreases when the percentage of timber ash is increased.

Table 12. Effects of use marble powder on compressive strength of concrete at different ages.

\begin{tabular}{|c|c|c|c|c|c|c|c|c|c|}
\hline \multirow{2}{*}{ Test } & \multirow{2}{*}{$\begin{array}{c}\text { Age of } \\
\text { sample } \\
\text { (days) }\end{array}$} & \multicolumn{8}{|c|}{ percentage replacement } \\
\hline & & \multicolumn{2}{|c|}{$0 \%$} & \multicolumn{2}{|c|}{$10 \%$} & \multicolumn{2}{|c|}{$20 \%$} & \multicolumn{2}{|c|}{$30 \%$} \\
\hline \multirow{12}{*}{$\begin{array}{c}\text { Compressive } \\
\text { Strength (MPa) }\end{array}$} & \multirow{4}{*}{7} & 21.5 & \multirow{4}{*}{22.4} & 20.9 & \multirow{4}{*}{20.4} & 16.9 & \multirow{4}{*}{17.2} & 15.0 & \multirow{4}{*}{14.9} \\
\hline & & 22.7 & & 20.3 & & $* 11.4$ & & 15.1 & \\
\hline & & 23.7 & & 20.5 & & 17.3 & & 14.8 & \\
\hline & & 21.9 & & 20.0 & & 17.5 & & 14.6 & \\
\hline & \multirow{4}{*}{28} & 31.6 & \multirow{4}{*}{31.2} & $* 21.2$ & \multirow{4}{*}{30.4} & 24.8 & \multirow{4}{*}{24.8} & 18.7 & \multirow{4}{*}{19} \\
\hline & & 31.3 & & 30.0 & & 25.0 & & 18.3 & \\
\hline & & 30.8 & & 29.8 & & 24.0 & & 19.8 & \\
\hline & & 31.1 & & 31.4 & & 25.5 & & 19.1 & \\
\hline & \multirow{4}{*}{56} & 33.6 & \multirow{4}{*}{33.3} & 34.7 & \multirow{4}{*}{33.8} & 26.1 & \multirow{4}{*}{26.7} & 23.1 & \multirow{4}{*}{22.9} \\
\hline & & 33.9 & & $* 18.6$ & & 26.9 & & 22.2 & \\
\hline & & 32.8 & & 33.6 & & 26.5 & & 23.5 & \\
\hline & & 32.9 & & 33.1 & & 27.3 & & 22.8 & \\
\hline
\end{tabular}

*This value was excluded from average calculation

Table 13. Average density of concrete specimens at at 7, 28 and 56 days, containing timber ash

\begin{tabular}{cccc}
\hline $\begin{array}{c}\text { Percentage } \\
\text { replacement }(\%)\end{array}$ & $\begin{array}{c}\text { Density at 7days } \\
(\mathrm{Kg} / \mathrm{m} 3)\end{array}$ & $\begin{array}{c}\text { Density at 28days } \\
(\mathrm{Kg} / \mathrm{m} 3)\end{array}$ & $\begin{array}{c}\text { Density at 56days } \\
(\mathrm{Kg} / \mathrm{m} 3)\end{array}$ \\
\hline 0 & 2400.42 & 2368 & 2368 \\
10 & 2256.1 & 2308.2 & 2308.2 \\
20 & 2272.3 & 2299 & 2299 \\
30 & 2281 & 2321.9 & 2275.6 \\
\hline
\end{tabular}

Table 14. Average slump test of fresh concrete containing timber ash

\begin{tabular}{cc}
\hline percentage replacement $(\%)$ & Slump $(\mathrm{mm})$ \\
\hline 0 & 18.5 \\
10 & 17 \\
20 & 15 \\
30 & 13.5 \\
\hline
\end{tabular}

\subsubsection{Compressive strength test results}

Table 15 indicates the influence of timber ash replacement with cement on the compressive strength of the concrete cubes. The results demonstrated that the inclusion of timber ash reduced strength at the 7th, 28th, and 56th days. For $0 \%$ replacement, the compressive strength results were $22.4,31.2$, and $33.3 \mathrm{MPa}$ at the $7 \mathrm{th}, 28 \mathrm{th}$, and 56th days, respectively. The compressive strength values at the 7th day decreased to $12.9 \%, 29.9 \%$, and $33.9 \%$, and subsequently, to $3.8 \%, 21.1 \%$, and $23.7 \%$ at the 28 th day for $10 \%, 20 \%$, and $30 \%$ timber ash replacement, respectively. At the 56th day, the compressive strength results decreased to $0 \%, 25.2 \%$, and $24.3 \%$ for $10 \%, 20 \%$, and $30 \%$ timber ash replacement, respectively.

Table 15. Effects of use timber ash powder on compressive strength of concrete at different ages

\begin{tabular}{|c|c|c|c|c|c|c|c|c|c|}
\hline \multirow{2}{*}{ Test } & \multirow{2}{*}{$\begin{array}{c}\text { Age of } \\
\text { sample } \\
\text { (days) }\end{array}$} & \multicolumn{8}{|c|}{ percentage replacement } \\
\hline & & \multicolumn{2}{|c|}{$0 \%$} & \multicolumn{2}{|c|}{$10 \%$} & \multicolumn{2}{|c|}{$20 \%$} & \multicolumn{2}{|c|}{$30 \%$} \\
\hline \multirow{12}{*}{$\begin{array}{c}\text { Compressive } \\
\text { Strength } \\
(\mathrm{MPa})\end{array}$} & \multirow{4}{*}{7} & 21.50 & \multirow{4}{*}{22.4} & 19.20 & \multirow{4}{*}{19.5} & 16.02 & \multirow{4}{*}{15.7} & 14.90 & \multirow{4}{*}{14.8} \\
\hline & & 22.70 & & $* 14.30$ & & 15.83 & & 15.30 & \\
\hline & & 23.77 & & 19.52 & & 15.50 & & 14.80 & \\
\hline & & 21.95 & & 19.83 & & 15.63 & & 14.40 & \\
\hline & \multirow{4}{*}{28} & 31.60 & \multirow{4}{*}{31.2} & 30.40 & \multirow{4}{*}{30} & 24.00 & \multirow{4}{*}{24.6} & 24.10 & \multirow{4}{*}{23.8} \\
\hline & & 31.35 & & 30.20 & & 24.20 & & 24.40 & \\
\hline & & 30.85 & & 30.10 & & 25.50 & & 23.10 & \\
\hline & & 31.10 & & 29.50 & & 24.90 & & 23.60 & \\
\hline & \multirow{4}{*}{56} & 33.60 & \multirow{4}{*}{33.3} & $* 18.10$ & \multirow{4}{*}{34.4} & $* 17.50$ & \multirow{4}{*}{24.9} & 24.30 & \multirow{4}{*}{25.2} \\
\hline & & 33.90 & & 33.10 & & 25.10 & & 27.00 & \\
\hline & & 32.80 & & 34.00 & & 24.70 & & 24.50 & \\
\hline & & 32.90 & & 36.20 & & 24.90 & & 25.10 & \\
\hline
\end{tabular}

*This value was excluded from average calculation 


\section{Conclusions}

The influence of cement replacement with glass powder, marble powder, and timber ash has been studied. The following conclusions are drawn based on the experimental work.

1) Workability decreases as the partial replacement level of glass powder, marble powder, and timber ash with cement increases.

2) The optimum percentage for the replacement of glass powder, marble powder, and timber ash with cement is nearly $10 \%$.

3) The compressive strength of concrete decreases if the replacement level increases from $10 \%$ to $30 \%$ for each replacement.

4) The replacement material can be used conveniently to produce high-quality concrete at $10 \%$ cement replacement after 56 days.

5) The compressive strength of $10 \%$ cement replacement at 56 days is nearly higher than the control sample for all the replacement materials.

6) The use of glass powder, marble powder, and timber ash can diminish the utilization of concrete and the related vitality interest effect on air contamination and $\mathrm{CO}_{2}$ emission.

\section{Acknowledgments}

The authors extend their gratitude to the Director and Staff of The Material and Soil Laboratories at IUG-Gaza for their unlimited help throughout the testing program. Special thanks are also directed to senior civil engineering students Yousef M. Hashem, Hany Z. Elwan, Ahmed M. Abo-sultan, Hashem M. Kishko, for helping the author in carrying out the experimental program.

\section{References}

[1].Hassani, A., H. Ganjidoust, and A.A. Maghanaki, Use of plastic waste (poly-ethylene terephthalate) in asphalt concrete mixture as aggregate replacement. Waste Management \& Research, 2005. 23(4): p. 322-327.

[2].Aliabdo, A.A., A.E.M.A. Elmoaty, and E.M. Auda, Re-use of waste marble dust in the production of cement and concrete. Construction and building materials, 2014. 50: p. 28-41.

[3].Rai, B., et al., Influence of Marble powder/granules in Concrete mix. International journal of civil and structural engineering, 2011. 1(4): p. 827.

[4].Poon, C.S., Lam, L., Wong, Y. L, A Study on High Strength Concrete Prepared with 2002.

[5].Elkhadiri, I., Diouri, A., Boukhari.A., Aride, J., Puertas, F, Mechanical behaviour of 2002.

[6].Malhotra, V.M., Role of Supplementary Commentating Materials in Reducing 1988.

[7].Ismail, Z.Z. and E.A. Al-Hashmi, Recycling of waste glass as a partial replacement for fine aggregate in concrete. Waste management, 2009. 29(2): p. 655-659.

[8].Shayan, A. and A. Xu, Performance of glass powder as a pozzolanic material in concrete: A field trial on concrete slabs. Cement and Concrete Research, 2006. 36(3): p. 457-468.

[9].Matos, A.M. and J. Sousa-Coutinho, Durability of mortar using waste glass powder as cement replacement. Construction and building materials, 2012. 36: p. 205-215.

[10]. ASTM C204, Standard Test Methods for Fineness of Hydraulic Cement by Air-Permeability Apparatus. American Society for Testing and Materials, 2004.

[11].ASTM C33, Standard Specification for Concrete Aggregates. American Society for Testing and Materials, 2004.

[12].ASTM C127, Standard Test Method for Specific Gravity and Absorption of Coarse Aggregate. American Society for Testing and Materials, 2004.

[130].ASTM C128, Standard Test Method for Specific Gravity and Absorption of Fine Aggregate. American Society for Testing and Materials, 2004.

[14].ASTM C566, Standard Test Method for Total Evaporable Moisture Content of Aggregate by Drying. American Society for Testing and Materials, 2004.

[15].ASTM C29, Standard Test Method for Bulk Density ("Unit Weight") and Voids in Aggregate. American Society for Testing and Materials, 2004.

[16].ASTM C136, Standard Test Method for Sieve Analysis of Fine and Coarse Aggregates. American Society for Testing and Materials, 2004.

[17].Tayeh, B.A., et al., Mechanical and permeability properties of the interface between normal concrete substrate and ultra high performance fiber concrete overlay. Construction and building materials, 2012. 36: p. 538-548.

[18] Tayeh BA, Abu Bakar B, Johari M, Zeyad A. The role of silica fume in the adhesion of concrete restoration systems. Advanced Materials Research: Trans Tech Publ; 2013. p. 265-9. 